\title{
Gereja Persekutuan Umat Allah
}

\author{
Novry Dien \\ Sekolah Tinggi Filsafat Seminari Pineleng \\ Novridien@gmail.com
}

\begin{abstract}
This essay deals with the idea of the church as the people of God according to Lumen Gentium, a Second Vatican Council's document on the catholic church. The author tries to explore and understand the historical background of this idea and its development. This idea can be traced in the patristic time when the church was still limited to some small communities in which the leadership of the church was more charismatic. As the Church grew bigger and needed to be organized, the role of the hierarchy was clearly emphasized and enjoyed its almost absolute privilege during the Middle Ages. The Church restored its initial understanding in the Second Vatican Council which opened the windows for active role of the lay persons in the life of the church, working together with the hierarchy to present salvation to the world. This essay also tries to explore some problem regarding this idea which arose in ecclesiological discourse after the Second Vatican Counsil.
\end{abstract}

\section{Keywords:}

Ekklesia, Tubuh Mistik Kristus, Gereja Hierarkis, Gereja Umat Allah, Lumen Gentium.

\section{PENDAHULUAN}

Konsili Vatikan II (1962-1965) membawa perubahan besar dalam hal gambaran dan pemahaman tentang Gereja. Bentuk hierarkis piramidal ditinggalkan karena tidak sesuai dengan situasi konkrit kontemporer. Seiring dengan ajakan untuk kembali ke sumber-sumber, Gereja memandang dirinya sekarang ini sebagai "Persekutuan Umat Allah". Ajaran demikian tentu lahir dari refleksi atas sejarah dan dari kesadaran untuk meninjau kembali bagaimana Gereja seharusnya hadir di tengah dunia.

Dalam uraian ini, penulis hendak menggali mengenai cara Gereja memandang dirinya sendiri menurut konstitusi dogmatis Lumen Gentium (LG). Paham eklesiologis LG lahir melalui refleksi terus-menerus tentang cara 
pandang Gereja tentang dirinya di dalam lintasan sejarah, tetapi juga di dalam konteks perubahan pola pikir manusia modern. Oleh karena itu, untuk mengerti secara lebih baik tentang paham Gereja sebagai persekutuan Umat Allah, kita perlu melihat juga paham-paham eklesiologis sepanjang sejarah sebelum KV II. Tidak bisa disangkal bahwa paham-paham ini turut membentuk pandangan Gereja dalam LG tersebut. Penulis terutama merujuk pada pandangan Yves Congar yang secara representatif merangkum perkembangan sejarah cara pandang Gereja. Congar menawarkan sebuah pemahaman eklesiologis yang sangat berpengaruh pada KV II.

\section{METODE}

Untuk menganalisa perkembangan paham Gereja sebagai umat Allah dan menemukan makna di balik paham itu, maka penulis dalam tulisan ini menggunakan metode tinjauan literatur (literatur review). Penulis mencoba menganalisa teks dokumen Gereja Lumen Gentium, terutama beberapa gagasan yang berkaitan dengan paham Gereja sebagai umat Allah. Penulis mendasarkan uraian ini para penulis ahli lainnya yang pernah membahas tentang pemahaman Gereja dalam Lumen Gentium, maupun untuk menggali sejarah pemahaman Gereja dan tanggapan para teolog kontemporer setelah KVII. Uraian penulis terutama merujuk pada tulisan Yves Congar.

\section{HASIL DAN PEMBAHASAN}

\section{Pemahaman Gereja Sebelum KV II}

Yves Congar ${ }^{1}$ adalah teolog yang cukup berpengaruh menjelang KV II. Pandangannya atas salah satu cara banyak menginspirasi pemahaman tentang Gereja dalam konsili. Ia mempelajari perkembangan bentuk-bentuk Gereja dan memberi penilaian atasnya. Berikut gambaran umum analisis Congar, dan secara lebih panjang diuraikan paham Tubuh Mistik sebagai persiapan pandangan Gereja Umat Allah.

\footnotetext{
1 Yves Congar memiliki nama lengkap Yves Marie Joseph Cardinal Congar. Ia lahir tahun 1904 dan meninggal tahun 1995. Ia adalah seorang imam dari ordo Dominikan. Ia dikenal sebagai teolog yang sangat berpengaruh di abad 20 dengan pemikiran-pemikiran yang tajam mengenai eklesiologi. Buah-buah pemikirannya cukup berpengaruh dalam KVII. Inti pandangannya adalah Gereja merupakan tubuh mistik Kristus, umat Allah dan sakramen keselamatan. Pandangan ini menyegarkan kembali pemahaman akan tugas Gereja ditengah dunia, dan mengangkat peran awam di dalamnya. Hal ini dapat ditemukan dalam beberapa tulisannya, dan yang banyak dikutip dalam tulisan ini dari buku "Gereja Hamba Kaum Miskin".
} 


\section{Gereja Primitif}

Sejak awal mula, umat kristen adalah sebuah persekutuan. Dalam analisisnya mengenai kekuasaan dalam Gereja, Congar menemukan bahwa umat kristiani purba (zaman para rasul hingga dekrit Konstantinus, atau dalam sudut pandang lain jaman patristik antara tahun 100-451) memandang diri mereka ekklesia. Di sini kata ekklesia dimengerti dalam arti pertama, yakni kumpulan atau persatuan umat Kristen. Di dalam persekutuan ini, kekuasaan berarti pelayanan satu sama lain. ${ }^{2}$

Teks-teks liturgi menggunakan juga istilah ekklesia yang berarti perkumpulan orang-orang yang dimungkinkan oleh tindakan Tuhan sendiri dan terjadi demikian karena kehadiran-Nya di antara mereka. ${ }^{3}$ Hal sama juga dikatakan oleh John Lynch. Ia menemukan bahwa dalam Didache (Ajaran Para Rasul yang ditulis sekitar abad ke-2) tugas liturgi yang awalnya milik para guru kini diserahkan kepada para diakon. Tahap akhir perkembangan tampak dalam tulisan Ignasius dari Antiokhia yang menyebut bahwa liturgi dan tindakan mengajar dipimpin oleh seorang uskup, dewan para tua-tua mengatur bersama dengan uskup, dan para diakon memperhatikan hal-hal praktis. ${ }^{4}$ Dengan demikian, institusionalisasi Gereja mulai terbentuk tahap demi tahap.

Congar melanjutkan bahwa meski karisma seorang uskup sangat penting, namun umat memiliki peran yang cukup menentukan dalam persekutuan. Umat sendiri menentukan kebiasaan yang mengatur hidup mereka. Mereka tunduk kepada uskup, karena mereka sendiri memilih dia menjadi uskup. Seseorang dipilih menjadi uskup karena karismanya yang tampak. ${ }^{5}$

\section{Gereja Hierarkis dan Peran Para Rahib}

Sejak Kaisar Konstantinus menyatakan Kristen sebagai agama yang diakui negara (313), terjadi perubahan dalam hidup Gereja. Negara memiliki tanggung jawab untuk mengurusi kebutuhan rohani warga. Kaisar sebagai pontifex maximus ikut mengatur persoalan agama. ${ }^{6}$ Struktur Gereja berkembang menye-

2 Bdk. Yves Congar, Gereja Hamba Kaum Miskin, terj. R. Hardjono (Yogyakarta: Kanisius, 1973), hal. 28-30.

3 Bdk. Ibid.

${ }^{4}$ Bdk. John Lynch, "Power in the Church: an Historico-critical Survey", Concilium: Power in The Church, eds. James Provost \& Knut Walf (AB Nijmegen, Holland: Stichting Concilium \& Edinburgh, Scotland: T.\&T. Clard Ltd, 1988), hal. 13-14.

5 Bdk. Congar, Gereja Hamba Kaum Miskin, hal. 30-31.

6 Bdk. Congar, Gereja Hamba Kaum Miskin, hal. 14. Hal itu bukan sebuah persoalan sampai akhirnya pada tahun-tahun berikut muncul pertentangan antara paus dan kaisar. Sejak Paus Gelasius I (492-496) dimengerti bahwa tujuan hidup manusia adalah rohani sehingga meski 
suaikan dengan sistem organisasi negara. Keputusan atas hal-hal menyangkut kebiasaan tidak lagi dibuat dalam kebersamaan dengan umat. Hal ini menjadi hak para uskup dalam konsili atau pertemuan. Dengan demikian, ikatan antara uskup dan umat yang dahulu bersifat karismatis bergeser pada penekanan terhadap otoritas. ${ }^{7}$

Dengan mendapat hak-hak istimewa, misalnya seorang uskup setara dengan senator, para rohaniwan mudah jatuh dalam hal-hal dan kekuasaan dunia. Hubungan di dalam Gereja mendapat corak kekaisaran, yakni sifat yuridis dengan pola atasan dan bawahan. Dalam situasi demikian, kebangkitan kerahiban menjadi semacam jalan keluar untuk kembali kepada hubungan rohaniwan dan awam yang karismatis. Ini adalah jalan untuk membimbing umat menjadi manusia rohani. Dalam sejarah, wilayah para rahib lambat laun menjadi otonom dan dipertentangkan dengan struktur hierarkis resmi. Misalnya, Gereja Keltis tidak dikenal organisasi diosesan, melainkan kumpulan umat sekitar biara dan di bawah kuasa seorang abbas (terkadang juga menjadi uskup). Kekuasaan rohani bukan berdasarkan penahbisan secara hierarkis, melainkan menurut martabat kesucian. ${ }^{8}$ Muncul pula tuntutan untuk melepaskan kekuasaan surgawi dari duniawi, meski yang pertama dipandang lebih dari yang kedua. ${ }^{9}$ Perlahan-lahan terjadi pemisahan yang jelas antara rohaniwan dan awam. Rohaniwan dianggap memiliki gaya hidup yang diidealkan. Jika dulu pertentangan terjadi antara Gereja dan dunia, kini di dalam Gereja terdapat pertentangan model hidup antara rohaniwan yang memegang kunci surga dan bukan rohaniwan dengan sifat duniawi. Perkembangan ini memuncak dalam pembaharuan Paus Gregorius VII, di mana Gereja dijadikan masyarakat rohani dengan kedaulatan penuh. ${ }^{10}$

Konsekuensi kedaulatan tersebut adalah berkurangnya unsur campur tangan Allah dalam Gereja dan meningkatnya pandangan Gereja sebagai sebuah sis-

ada dua kuasa (duniawi dan ilahi), kuasa kaisar di bawah kuasa rohani paus. Namun, Paus juga menjanjikan kepada kaisar bahwa para uskup tunduk pada penguasa sipil. Bdk. Tom Jacobs, "Gereja dan Dunia", dalam Gereja dan Masyarakat, ed. JB. Banawiratma (Yogyakarta: Kanisius, 1986), hal. 15-16.

7 Bdk. Lynch, "Power in the Church", hal. 14-16.

8 Bdk. Congar, Gereja Hamba Kaum Miskin, hal. 31-33. Abbas yang juga adalah uskup pada zaman ini antara lain: Basilius, Yohanes Krisostomos, Agustinus, Martinus, Germanus dari Auxerre, Patrisius, Eukarius dari Lyon, Faustus dari Riez, Lupus dari Troyes, Gregorius Agung, para uskup anggung Canterbury sampai abad ke dua belas.

9 Bdk.Jacobs, "Gereja dan Dunia", hal. 15.

${ }^{10}$ Bdk. Congar, Gereja Hamba Kaum Miskin, hal. 37-38. 
tem yang ditopang dengan hukum. Subjek hukum adalah para roha niwan, dan lebih tepatnya kaum hierarkis. Itulah Gereja dengan model hierarkis, di mana Paus berada di puncak kekuasaan, kemudian para uskup dan para imam. Umat dipandang sebagai objek dari hukum dan kegiatan Gereja. ${ }^{11}$

\section{Gereja Tubuh Mistik Kristus}

Sejak abad ke-12 mulai terjadi sekularisasi. Ilmu pengetahuan yang dulu hanya milik Gereja dan demi kepentingan teologi kini mulai menjadi profan. Puncak dari perkembangan itu adalah Renaissance dengan pandangan antroposentrisme. Seiring dengan kemerosotan moral para rohaniwan, Gereja perlahan-lahan mulai kehilangan pengaruh dalam masyarakat. Reaksi bermunculan di mana-mana seperti gerakan Protestantisme dan juga Revolusi Prancis (pengakuan kedaulatan negara sekuler). Reaksi itu positif sebagai usaha untuk melihat peran manusia dalam mengembangkan dunia. Tetapi faktor pendorongnya adalah reaksi melawan kuasa tak terbatas pimpinan Gereja. ${ }^{12}$ Tanggapan dari Gereja dalam Konsili Trente membentuk gambaran Gereja yang sentralistis di Roma. Peran dan kekuasaan paus atas Gereja sangat ditonjolkan. Roma (atau Paus) mengatur segala yang berhubungan dengan liturgi, pedoman-pedoman sakramen, tentang orang kudus, kegiatan kerasulan dan penerbitan. Taat pada Allah sama dengan taat pada Paus. ${ }^{13}$

Eklesiologi dan teologi yang dikembangkan adalah ajaran Paulus dalam Efesus 5, yakni "Tubuh Mistik". ${ }^{14}$ Tubuh adalah gambaran kesatuan antara yang berbeda-beda, namun saling melengkapi. Tubuh yang dimaksud di sini adalah keseluruhan Gereja, di mana kepalanya adalah Yesus. Kekuasaan Allah hadir dalam tubuh, yakni Gereja. ${ }^{15}$ Pemahaman ini dikukuhkan dalam Ensiklik Mystici Corporis Christi oleh Paus Pius XII pada tahun 1943. Dalam ensiklik tersebut, Paus menegaskan bahwa kesatuan Kristus dan Gereja tidak menghapus perbedaan pribadi antara Kristus dan anggota-anggota Tubuh. Kata "mistik" juga tidak berarti tidak dapat dilihat. Tubuh mistik ini adalah Gereja Katolik Roma. Dengan demikian, tak seorang pun dapat menjadi bagian dari Tubuh mistik tanpa menjadi anggota Gereja Katolik Roma. Menurut pemahaman ini, institusi-institusi lain tidak masuk dalam persekutuan dengan

\footnotetext{
11 Bdk. Ibid., hal. 40-42.

12 Bdk. Jacobs, "Gereja dan Dunia", hal. 15-18.

13 Bdk. Congar, Gereja Hamba Kaum Miskin, hal. 44-45.

${ }^{14}$ Ef 5:23 "karena suami adalah kepala isteri sama seperti Kristus adalah kepala jemaat."

15 Bdk. Congar, Gereja Hamba Kaum Miskin, hal. 43-44.
} 
Yesus sebagai kepala Tubuh, karena mereka tidak mengambil bagian dalam persekutuan iman dalam Gereja Katolik, dalam sakramen-sakramen dan ketaatan.

Paham eklesiologis di atas memunculkan perdebatan sehubungan dengan pembaptisan yang sah yang mempersatukan penerima dalam Tubuh Kristus. Persoalan terlebih dialami para teolog ekumenis. Mereka menyatakan bahwa ajaran Paus dalam ensiklik tersebut tidak sejalan dengan teologi Paulus mengenai pembaptisan. Persoalan tersebut membuat Paus Pius XII mengeluarkan ensiklik baru yang mengajarkan bahwa oleh pembaptisan orang Kristen menjadi anggota Tubuh Mistik dan ikut berpartisipasi dalam tugas imamat Kristus. ${ }^{16}$

Yves Congar dalam tulisan-tulisannya memberi pandangan bahwa Gereja didirikan oleh Kristus. Gereja dijiwai oleh Roh Kristus, dan sekaligus dari bawah oleh manusia yang dapat bersalah dan berdosa. Dengan meneliti pengalaman Gereja primitif, Congar menemukan bahwa sebelum didominasi oleh kekuasaan, Gereja memiliki spiritualitas yang intens, sikap doa yang mendengarkan Kristus, keterbukaan atas pertobatan dan pembaharuan. Pada tahun-tahun berikut, Gereja didominasi kekuasaan dan serentak Gereja mendominasi dunia. Meski hal itu dapat dimengerti, namun jelas bahwa Gereja mula-mula memberikan model yang lebih baik. Gereja tidak perlu mendominasi masyarakat, tetapi perlu menarik hati dan pikiran banyak orang. Ia juga mulai berpikir tentang pandangan Gereja umat Allah. Baginya, pandangan Tubuh Mistik adalah satu hal saja. Ada juga ungkapan Gereja sebagai "kenisah Roh Kudus" yang mengangkat dimensi interior dan spiritualitas. Struktur institusional adalah sarana semata karena Gereja adalah suatu masyarakat dalam Roh (congretatio fidelium). ${ }^{17}$

Sudut pandang Congar memiliki konsekuensi bagi konsep-konsep eklesiologis dan teologis pada umumnya. Antara lain, awam tidak dilihat lagi sebagai objek pelayanan hierarkis, melainkan subjek aktif pelayanan. Awam juga memiliki peran dan tanggung jawab dalam Gereja. Peran khusus mereka adalah mengubah dunia dengan terang Injil. Tugas mereka bukan mandat dari hierarkis tetapi karena iman dan pembaptisan. Dalam kaitan dengan eskatologi,

\footnotetext{
${ }^{16}$ Bdk. Avery Dulles, "Setengah Abad Eklesiologi", dalam Gereja Dalam Perubahan, ed. G. Kirchberger (Ende: Nusa Indah, 1992), hal. 13-16.

17 Bdk. Ibid., hal. 16-18.
} 
Gereja dipandang sebagai umat Allah yang berziarah dalam perjalanan menuju ke surga. Dalam kaitan dengan sakramen, Gereja memang tanda efektif sakramen, tapi rahmat tidak harus bergantung pada keanggotaan aktual dalam Gereja. $^{18}$

\section{Gereja Umat Allah dalam Lumen Gentium}

Konstitusi Dogmatis Lumen Gentium tentang Gereja dihasilkan pada sidang ke lima KV II, yakni pada tanggal 21 November 1964. Konstitusi dogmatis ini dibagi atas delapan bab, yakni bab I (Misteri Gereja), bab II (Umat Allah), bab III (Susunan Hierarkis Gereja, Khususnya Episkopat), bab IV (Para Awam), bab V (Panggilan Umum untuk Kesucian dalam Gereja), bab VI (Para Religius), bab VII (Sifat Eskatologis Gereja Musafir dan Persatuannya dengan Gereja di Surga), bab VIII (Santa Perawan Maria Bunda Allah dalam Misteri Kristus dan Gereja). Tampak jelas bahwa fokus konstitusi dogmatis ini adalah membahas Gereja di dalam dirinya sendiri (ad-intra).

\section{Kelanjutan Ajaran Sebelumnya}

Eklesiologi Lumen Gentium tidak terlepas dari arus pemikiran dan ajaran Gereja sebelumnya. Meski awalnya Paus Pius XII menyatakan bahwa Tubuh Mistik sama dengan Gereja Katolik, kritik para teolog ekumenis mendorongnya untuk menjelaskan kembali bahwa seseorang menjadi anggota Tubuh Kristus berkat permandian. Ajaran ini diteruskan dalam KV II. Dalam LG 7 dinyatakan bahwa kepenuhan Kristus bukan diturunkan dari Gereja, tetapi "memenuhi" (subsist in) Gereja. ${ }^{19}$

Yesus telah mengumpulkan saudara-saudara-Nya dari segala bangsa, dan dengan mengaruniakan Roh-Nya, Ia secara gaib membentuk mereka menjadi Tubuh-Nya. Dalam Tubuh itu hidup Kristus dicurahkan ke dalam umat beriman... Dengan kekuatan-Nya yang agung Ia berdaulat atas langit dan bumi; dan dengan kesempurnaan serta karya-Nya yang amat luhur Ia memenuhi seluruh Tubuh dengan kekayaan kemuliaannya... Ia memenuhi Gereja, yang merupakan Tubuh dan kepenuhan-Nya, dengan kurnia-kurnia ilahi-Nya, supaya Gereja menuju dan mencapai segenap kepenuhan Allah (LG 7).

${ }^{18}$ Bdk. Ibid., hal. 19-20.

${ }^{19}$ Bdk. George H. Tavard, The Church, Community of Salvation (Manila: St. Pauls, 1997), hal. 86. 
Satu pertanyaan penting yang menjadi refleksi sebelum dan sesudah konsili adalah apakah Gereja itu memiliki realitas ilahi atau insani. Pertanyaan itu dijawab dalam LG 8. Sebagai Tubuh Kristus, Gereja menjadi baik komunitas iman, harap dan kasih, maupun sebuah organisasi yang dipimpin oleh hierarki dan tampak secara konkret. Gereja sekaligus komunitas spiritual dengan segala kebaikan yang berasal dari surga, sekaligus komunitas umat beriman yang ada di tengah dunia. ${ }^{20}$ Sebagai komunitas spiritual, Gereja memiliki aspek misteri, menjadi sakramen (sebagai mana lebih lengkap diuraikan dalam Konstitusi Pastoral Gaudium et Spes), keselamatan dan persekutuan rahmat. Sebagai realitas duniawi, dalam Gereja ada struktur institusional dan pimpinan. Dua hal itu tidak dapat dilihat sebagai hal terpisah sama sekali dan tetap menunjukkan Gereja yang satu dan sama. Refleksi atas peran hierarki searah dengan pandangan Congar. Hierarki harus dilihat dalam konteks pelayanan bukan penguasaan atau pemerintahan. Hierarki adalah pelayan bagi umat Allah. Awam terlibat dalam tugas pelayanan tersebut berkat pembaptisan yang mereka terima. Di sini dibedakan antara imamat Yesus, imamat khusus (karena tahbisan) dan imamat umum. ${ }^{21}$

\section{Bentuk Gereja Umat Allah}

Konsep Gereja Umat Allah adalah buah refleksi dari sejarah keselamatan hingga saat itu. Yang ditekankan dalam refleksi tersebut adalah persekutuan umat Allah dalam Perjanjian Lama (PL), ajaran-ajaran Paulus dan teologi Patristik. Menyangkut hal yang terakhir, secara umum dapat dikatakan bahwa ada dorongan bagi para bapak konsili untuk kembali ke akar, dalam hal ini konsep-konsep eklesiologi awal. Sehingga, penekanan-penekanan yang muncul bukan dari ajaran skolastik tetapi teologi patristik.

Dalam PL diceritakan bagaimana Allah memilih Abraham dan keturunannya yakni bangsa Israel (bdk. Kej 12:1-9). Hubungan tersebut diikatkan dengan perjanjian bahwa Ia menjadi Allah mereka, dan mereka menjadi umat-Nya. Kepada mereka dijanjikan seorang Juru Selamat (bdk. 2Sam 7:12-14; Yes 9:1-7; Zak 9:9-10). Ia akan menjadi penebus dosa seluruh umat manusia (Yoh 1:29). Kedatangan Yesus adalah kepenuhan janji tersebut. Kedatangannya menjadi saat di mana "Israel lama" digantikan dengan "Israel Baru" yang hidup menurut Roh dan dalam kuasa kebangkitan. Mereka adalah umat Allah sudah

\footnotetext{
20 Bdk. Tavard, The Church, hal. 86.

${ }^{21}$ Bdk. Dulles, "Setengah Abad Eklesiologi", hal. 21-22.
} 
menerima penyelamatan dari sang Mesias. Mereka adalah umat Allah yang menjadi demikian karena persatuan dengan sang penyelamat. ${ }^{22}$

Pemahaman Umat Allah dalam salah satu cara sesuai dengan pandangan sosial-politik jaman itu. Tidak dapat dikatakan bahwa hal ini mempengaruhi secara langsung konsili, namun jelas bahwa masa itu ditandai dengan kebangkitan kesadaran akan pentingnya demokrasi dan modernisasi. Intinya adalah mengangkat kekuatan masyarakat atau umat. Ideologi seperti sosialisme bicara mengenai keberpihakan terhadap masyarakat. Sedangkan, komunisme bicara mengenai persamaan semua warga masyarakat.

Bagaimana bentuk dari Gereja Umat Allah ini? Apakah pemenuhan dari umat Perjanjian Lama atau sama dengan paham masyarakat seperti dalam pengertian sosial-politik modern? LG menjelaskan bahwa umat Allah yang dimaksud adalah sebuah partisipasi dalam tritugas Yesus, yakni memimpin, menguduskan dan mewartakan. Dalam tugas memimpin, Gereja mengambil bagian dalam kepemimpinan Yesus dengan hidup dalam kemuliaan dan kebenaran, serta senantiasa mengarahkan diri kepada kerajaan Allah. Kemuliaan Kerajaan Allah dicapai secara sempurna di surga (LG 48), namun antisipasinya saat ini dalam Gereja. Hal itu mungkin karena rahmat ilahi dan pelaksanaannya dalam komunitas. ${ }^{23}$

Dalam tugas menguduskan, Gereja menjadi sakramen yakni tanda kesatuan antara umat manusia dengan Allah dan kesatuan seluruh umat manusia (LG 1). Allah sendiri memanggil mereka yang mengarahkan diri pada Yesus dan membentuk mereka menjadi Gereja. Kesatuan itu adalah sakramen kelihatan sehingga melaluinya keselamatan terlaksana (LG 9). Dasar dari daya menguduskan Gereja adalah Roh Kristus yang diutus dalam hati para murid yang kemudian membentuk Gereja (LG 48). ${ }^{24}$

Dalam tugas mewartakan, Gereja adalah umat profetis dengan iman akan Allah yang tidak dapat runtuh. Umat memiliki rasa iman menyangkut keyakinan dan moral. Hal itu dilindungi oleh Roh Kudus agar tidak keliru. Dengan ini, seluruh umat manusia dirangkul untuk menjadi satu dengan Gereja yang adalah umat Allah. ${ }^{25}$

\footnotetext{
${ }^{22}$ Bdk. Tavard, The Church, hal. 87.

${ }^{23}$ Bdk. Ibid., hal. 88.

24 Bdk. Jacobs, "Gereja dan Dunia”, hal. 24-25.

${ }^{25}$ Bdk. Tavard, The Church, hal. 88.
} 
Sebagai umat Allah, Gereja juga dipahami sebagai Gereja yang sedang berziarah. Pokok ini secara lengkap dibahas dalam bab tujuh LG. Di sini diangkat aspek eskatologis, yakni hubungan persekutuan saat ini dengan persekutuan abadi dengan para kudus. Sejajar dengan teologi Congar, Gereja dipandang sebagai awal kerajaan eskatologis. ${ }^{26}$

\section{Wujud Gereja Umat Allah ${ }^{27}$}

Dalam konsep individualisme keselamatan, Gereja dipandang sebagai sarana yang melayani kebutuhan masing-masing orang. KV II dengan konsep Gereja sebagai umat Allah menolak pandangan tersebut. Memang masingmasing orang menanggapi panggilan Allah secara personal. Tapi keputusan tersebut menghantar pada sebuah persekutuan dalam menghayati hidup yang baru tersebut. Gereja mungkin dapat dipandang sebagai sarana, tapi tujuannya adalah agar manusia mencapai kebahagiaan abadi dalam persekutuan dengan Allah Tritunggal. Dijelaskan bahwa persekutuan Allah dengan manusia yang diciptakan Yesus melalui hidup-Nya dilanjutkan oleh Roh Kudus yang berdiam dalam hati umat beriman (LG 4). Dengan itu masing-masing orang mengambil kodrat ilahi.

Persekutuan dengan orang beriman paling tampak dalam persekutuan dengan jemaat setempat yang berkumpul merayakan Ekaristi (LG 26). Jemaat itu bersama-sama dipanggil untuk membangun persekutuan dengan jemaat lain, sehingga terbentuk Gereja Universal. Jaminan persekutuan Gereja setempat adalah persatuan para imam dengan uskup sebagai gembala utama. Hubungan antara Gereja partikular dijamin dengan kolegium para uskup dengan uskup Roma sebagai kepalanya (LG 23). Kolegium para uskup ini adalah landasan kelihatan saja. Landasan utamanya adalah Roh Kudus (LG 22). Roh Kudus menjaga dengan utuh bentuk kepemimpinan yang diberikan Kristus dalam Gereja-Nya (LG 27). Pokok mengenai kepemimpinan dijelaskan pada poin berikut.

Panggilan menjadi murid Kristus tak dapat dimengerti di luar communio. Dengan daya Roh Kudus, orang menjadi manusia baru dan dengan sendiri menjadi anggota umat Allah, itulah Tubuh Kristus. Panggilan selalu merupakan sebuah perutusan. Dengan demikian, panggilan ke dalam persekutuan adalah

\footnotetext{
${ }^{26}$ Bdk. Dulles, "Setengah Abad Eklesiologi", hal. 22.

${ }^{27}$ Bdk. Georg Kirschberger, "Jemaat dan Pastornya dalam Terang Eklesiologi Konsili Vatikan II", dalam Gereja dalam Perubahan, ed. Georg Kirschberger (Ende: Nusa Indah, 1992), hal. 57-83.
} 
panggilan kepada actuosa participatio (partisipasi aktif) baik dalam konteks liturgi (SC 14), tapi juga dalam seluruh hidup dan tugas perutusan Gereja. Setiap anggota umat Allah mewujud-nyatakan peran Kristus secara konkret (LG 10-12, 34-36). Peran itu baik ke dalam maupun ke luar diri Gereja.

\section{Hubungan Awam dan Hierarki}

Dalam penjelasan tentang tugas kaum tertahbis dan para awam, terungkap bagaimana relasi antara awam dan kaum hierarki:

Uskup mempunyai kepenuhan sakramen tahbisan, maka ia menjadi "pengurus rahmat imamat tertinggi", terutama dalam Ekaristi... Gereja Kristus sungguh hadir dalam jemaat beriman setempat yang sah, yang mematuhi para gembala mereka, dan Perjanjian Baru yang disebut Gereja... Di jemaat-jemaat meski hanya kecil dan miskin, atau tinggal tersebar, hiduplah Kristus... Para uskup dengan berdoa dan bekerja bagi Umat, membagikan kepenuhan kesucian Kristus dengan pelbagai cara dan secara melimpah... (LG 26)

... Tugas mereka [para gembala] yang mulia adalah mengembalakan umat beriman dan mengakui pelayanan-pelayanan serta kurnia-kurnia mereka sedemikian rupa, sehingga semua saja dengan cara mereka sendiri sehatisejiwa bekerja sama untuk mendukung karya bersama... (LG 30)

Umat setempat tidak dapat dipandang sebagai bagian administratif dari Gereja universal atau dari satu diosesan. Mereka sungguh sebuah Gereja, karena di dalamnya Gereja hadir secara konkret. Gereja dalam arti penuh itu adalah keuskupan yang dipimpin oleh seorang uskup. Tetapi umat yang dipimpin pastor di bawah kuasa uskup sungguh menghadirkan Gereja Kristus. Dalam Ekaristi tampak persekutuan umat beriman, dan sekaligus Ekaristi menjadi sumber bagi persekutuan umat. Sakramen lain turut serta dalam menguatkan jemaat.

Hierarki dipandang sebagai tanda Kristus yang hidup di tengah umat. Roh Kudus mempersatukan pribadi-pribadi. Ia tidak menyamaratakan semua orang, melainkan mengembangkan kekhasan mereka masing-masing. Dalam pandangan ini, Gereja sebagai institusi tidak ditolak, tetapi diberi sifat rohani. Melalui hierarki Kristus tetap rela berkarya di tengah umat. Hal ini menunjukkan betapa penting peran hierarki, tetapi sekaligus menegaskan batasan peran mereka tersebut. Hal yang dimaksud di sini adalah hierarki ada dan sangat diperlukan untuk melayani Kristus dan umat. Dalam pelayanan tersebut paus, uskup dan para imam menjalankan tritugas Yesus yaitu mengajar, memimpin 
dan menguduskan. Dalam kaitan dengan mengajar, masalah doktrin Gereja dan kebijakan menjadi reservasi kepada magisterium, dan di luar kewenangan awam.

Wujud nyata pemahaman ini terletak pada penegasan kembali peran uskup setempat. Uskup menjadi tanda kesatuan umat, dan para imam bekerja di bawah uskup. Meskipun imam bukan bertindak atas nama uskup, melainkan atas nama Kristus. Hal ini menghapus pandangan bahwa seolah-olah Gereja hanyalah kelompok hierarki saja. Gereja adalah umat setempat yang konkret, yang saling mengenal satu dengan yang lain dan yang mengimani Yesus secara bersama-sama.

\section{Eklesiologi Sesudah Konsili Vatikan II}

Menurut Tavard, pandangan Gereja Umat Allah mengandung ambiguitas yang menyebabkan berbagai kekacauan, seperti ketidakpercayaan pada otoritas. $^{28}$ Namun, para teolog dan praktisi beru saha untuk mengerti, menjelaskan, serta mengkontekstualisasikan ajaran konsili tersebut. Hal inilah yang coba digali oleh Avery Dulles dalam tulisannya mengenai penilaiannya terhadap beberapa teolog kontemporer, seperti dalam uraian berikut. ${ }^{29}$

\section{Para Teolog Besar di Barat}

Menyangkut ke dalam, para teolog Barat bersoal jawab mengenai konsekuensi pandangan bentuk Gereja Umat Allah. Sedangkan ke luar, mereka berhadapan dengan ekumenisme dan peran Gereja dalam dunia. Dua persoalan ini mendorong mereka untuk menjelaskan seperti apa Gereja Umat Allah tersebut.

Tampak dalam tulisan-tulisannya antara tahun 1946-1984, Rahner lebih mendukung Gereja karismatis dari pada institusional. Bagi Rahner, sejarah keselamatan adalah tindakan Bapa. Puncak sejarah tersebut adalah Yesus. Gereja melanjutkan sejarah tersebut di mana Roh membangkitkan impuls karismatis di luar batas kontrol Gereja sebagai institusi. Gereja terlebih adalah sakramen yang memiliki daya keselamatan, baik bagi anggota tapi juga bagi yang lain yang terarah padanya. Bagi Rahner, inkarnasi Logos membuat semua manusia secara ontologis dikuduskan bagi Allah. Gereja memang tanda rahmat,

${ }^{28}$ Bdk. Tavard, The Church, hal. 88

${ }^{29}$ Bdk. Dulles, "Setengah Abad Eklesiologi", hal. 22-33. 
namun bukan sebab rahmat, apalagi alat rahmat. Gereja adalah hasil dari rahmat Allah. Untuk itu Gereja harus terbuka, demokratis dan bebas dari klerikalisme. Sebagai tanda rahmat, Gereja perlu mengambil peran dalam persoalan sosialpolitik masyarakat secara konkrit.

Hans Küng sangat menekankan keadaan Gereja sebagai Gereja berdosa. Bagi dia, kekayaan material Gereja sangat bertentangan dengan Kerajaan Allah yang diwartakan Yesus. Peran Gereja adalah sebagai komunitas yang terpanggil untuk menaati dan mewartakan Injil. Ia sangat menentang dominasi Gereja dan menggambarkan tugas paus yang tidak sesuai dengan ajaran mengenai keprimatan dan infalibilitas.

Louis Bouyer bicara mengenai aktualisasi Gereja paling intens dalam Gereja Lokal, dan secara khusus dalam perayaan Ekaristi. Uskup memili ki peran sebagai imam. Ia terpilih untuk memimpin dewan imam, sehingga sudah seharusnya ia menjalankan lagi pelayanan sabda, sakramen dan karya pastoral, bukan menjadi teknokrat eklesial. Umat awam berpartisipasi dalam mengkonsekrasi realitas sehari-hari melalui perannya juga dalam Ekaristi.

Para teolog kemudian seperti Jean Danielou, Henri de Lubac, Hans Urs von Balthasar dan Joseph Ratzinger kembali menekankan kenyataan ilahi dari Gereja sebagai sebuah organisme. Dalam konteks ini, Gereja lokal dimengerti sebagai organ-organ yang di satu sisi otonom, tetapi di sisi lain ada dalam kesatuan utuh yang memungkinkan dia hidup. Sebagai organisme, Gereja dijiwai secara ilahi untuk menjadi pengantin Kristus, sehingga tidak dapat direduksi hanya sebagai alat membangun masyarakat sekuler. Ungkapan yang populer adalah societas perfecta. Terkandung dalam ungkapan tersebut pemahaman mengenai pentingnya otoritas yang menyatukan umat dan rahmat sakramen yang membuatnya sempurna. ${ }^{30}$ Mereka mengkritik pandangan teologi sekuler dan teologi pembebasan. Mereka menegaskan bahwa karisma berkaitan dengan tugas dalam Gereja, dan secara khusus dalam jabatan Paus. Sehingga, pembaharuan struktur Gereja menurut teori manajemen kepemimpinan kontemporer ditolak. Pembaharuan yang benar lebih bersifat batiniah dan spiritual, sehingga yang dibutuhkan adalah kerendahan hati dan ketaatan, serta penghargaan terhadap otoritas dan tradisi.

${ }^{30}$ Bdk. Paul D.L. Avis, "Ecclesiology", dalam The Blackwell Encyclopedia of Modern Christian Thought, ed. Alister E. McGrath (Oxford \& Cambridge: Blackwell Publishers, 1993), hal. 130131. 


\section{Teologi Sekuler dan Politik}

Beberapa teolog, terlebih di negara-negara maju, mengembangkan teologi sekuler dan politik. Pandangan-pandangan ini berusaha untuk mengatasi kecenderungan introversi Gereja, dan mengharapkan Gereja yang lebih tanggap terhadap situasi konkret dunia. Menurut pandangan ini, Gereja pada dasarnya adalah organisasi yang melayani umat manusia. Untuk itu, Gereja seharusnya dapat membangun masyarakat menjadi lebih adil dan manusiawi.

Paham Gereja Umat Allah di Amerika Utara bersentuhan dengan paham pragmatismus. Gereja dilihat dari segi fungsinya bagi umat maupun bagi masyarakat. Sehingga entah sebagai institusi maupun sebagai kenyataan ilahi, Gereja tidak ada artinya jika tidak memiliki manfaat apa-apa bagi kemajuan. Menurut Richard P. McBrien, tidak ada alasan untuk membenarkan Gereja, jika Gereja tidak mengusahakan kesatuan manusia, tidak mampu mengabdikan dirinya untuk menyelesaikan perpecahan dalam umat manusia, dan tidak sanggup menegakkan prinsip-prinsip keadilan, cinta kasih dan damai, atau tidak berpartisipasi dalam menyelesaikan usaha mencapai tujuan tersebut. Dalam buku The Church, ia menjelaskan bahwa eklesiologi modern memandang Gereja sebagai misteri atau sakramen dan sebagai pelayan. Sebagai pelayan, ia adalah "agen keadilan dan perdamaian bagi dunia serta pertolongan dan advokat bagi orang miskin dan lemah." ${ }^{31}$

Di Jerman, Johann Baptist Metz juga menekankan hal yang sama. Ia menyebut sikap Gereja demikian sebagai "spiritualitas introvert". Gereja seharusnya menjadi "institusi kebebasan kritis iman." Ia sangat tidak setuju dengan kecenderungan Katolik sebagai agama borjuis dan menekankan peran Gereja terhadap pembaharuan sosial bagi seluruh masyarakat. Pandangan ini sangat menginspirasi teologi pembebasan Amerika Latin.

\section{Gereja Pembebasan Amerika Latin}

Para teolog pembebasan Amerika Latin juga mengkontekstualisasikan paham Gereja sebagai Umat Allah dalam kondisi sosial politik setempat. Gustavo Gutierrez di Peru mengemukakan bahwa Gereja harus menjadi tanda kehadiran Tuhan dalam pembebasan dan perjuangan membentuk masyarakat yang lebih adil dan manusiawi. Ia melihat struktur-struktur Gereja yang ada

31 "An agent of justice and peace in the world and aid to, and advocacy for, the poor and the powerless." Richard P. McBrien, The Church: The Evolution of Catholicism (USA: Harper Collins Publishers, 2008), hal. 361. 
sudah usang dan tidak mampu menjawab tantangan-tantangan yang baru. Gereja perlu dibangun dari bawah, yakni dari orang-orang miskin dan terpinggirkan.

Marcello Azevado mengemukakan peran penting komunitas basis Gereja. Dalam komunitas ini Injil diwartakan. Komunitas ini melayani dunia dengan memajukan transformasi sosial dan menghapus ketidakadilan. Setiap kelompok menjadi tanda nyata dan sakramen Kerajaan Allah yang akan datang.

Leonardo Boff juga menekankan hal yang sama, yakni mengenai peran kelompok basis. Ia menganggap institusi Gereja tidak penting, dan menekankan ciri kharismatis. Gereja lokal bukan sebuah dioses di bawah pimpinan uskup tetapi dihubungkan dengan analogi komunitas rumah, seperti dalam tulisan Paulus. Perkumpulan spontan kaum awam, dengan digerakkan oleh Roh Kudus, membangun kembali Gereja dari bawah.

\section{KESIMPULAN}

Refleksi mengenai bentuk Gereja ada dalam dua ketegangan antara Gereja sebagai institusi yang hierarkis dan Gereja kharismatis. Cara berpikir abad pertengahan memungkinkan Gereja hierarkis sebagai bentuk paling tepat yang dapat menjamin keberlangsungan Gereja dalam menghadirkan Kristus dan karya penyelamatan-Nya di tengah umat. Namun, seiring dengan perkembangan paham manusia (antropology) bentuk Gereja hierarkis telah menjadi semacam batu sandungan yang bukan hanya tidak lagi bisa menjawab kebutuhan umat pada umumnya, tetapi memunculkan berbagai macam persoalan seperti penyalahgunaan kuasa dan wewenang. Hal ini memunculkan banyak refleksi teologis yang menekankan aspek kharismatis dari Gereja.

Konsili Vatikan II dalam Konstitusi Dogmatis Lumen Gentium memberikan pemahaman yang proporsional mengenai bentuk Gereja yang menjamin hidupnya iman dalam umat. Itulah bentuk Gereja sebagai Umat Allah. Masingmasing anggota memiliki peran khas dalam mewujudkan tritugas Yesus: memimpin, menguduskan, mewartakan. Umat sendiri adalah tanda nyata kehadiran Kristus, sehingga bukan menjadi objek pelayanan tapi juga subjek aktif sesuai dengan tugasnya. Sedangkan hierarki adalah tanda Kristus yang hidup di tengah umat. Dengan demikian, hierarki diperlukan untuk melayani Kristus dan umat seperti dalam hal sakramen-sakramen, sekaligus umat menjadi pelayan satu dengan yang lainnya. 


\section{DAFTAR KEPUSTAKAAN}

Avis, Paul D.L. "Ecclesiology." dalam The Blackwell Encyclopedia of Modern Christian Thought, ed. Alister E. McGrath. Oxford \& Cambridge: Blackwell Publishers, 1993: 127-140.

Congar, Yves. Gereja Hamba Kaum Miskin, terj. R. Hardjono. Yogyakarta: Kanisius, 1973.

Dulles, Avery. "Setengah Abad Eklesiologi." dalam Gereja Dalam Perubahan, ed. G. Kirchberger. Ende: Nusa Indah, 1992: 11-39.

Jacobs, Tom. "Gereja dan Dunia." dalam Gereja dan Masyarakat. ed. JB. Banawiratma. Yogyakarta: Kanisius, 1986: 13-46.

Kirschberger, Georg. "Jemaat dan Pastornya dalam Terang Eklesiologi Konsili Vatikan II." dalam Gereja dalam Perubahan, ed. Georg Kirschberger. Ende: Nusa Indah, 1992: 57-91.

Konstitusi Dogmatis tentang Gereja, Lumen Gentium. Konstitusi Pastoral tentang Gereja dalam Dunia Modern, Gaudium et Spes. Konstitusi tentang Liturgi Suci, Sacrosanctum Concilium. Terjemahan Indonesia. Jakarta: KWI, 1993.

Lynch, John. "Power in the Church: an Historico-critical Survey." Concilium: Power in The Church, ed. James Provost \& Knut Walf. AB Nijmegen, Holland: Stichting Concilium \& Edinburgh, Scotland: T.\&T. Clard Ltd, 1988: 13-22. McBrien, Richard P. The Church: The Evolution of Catholicism. USA: Harper Collins Publishers, 2008.

Tavard, George H. The Church, Community of Salvation. Manila: St. Pauls, 1997. 